tion (London, 1751-4); EO $\left(\mathrm{Dal}^{2}\right)$, the second French edition of $\mathrm{T}$. Dalibard (Paris, 1756); EO (Wilcke), the German version of J. C. Wilcke (Leipzig, 1758). For titles of these editions see under Franklin in the Bibliography.

FN I. B. Cohen. Franklin and Newton. Philadelphia, 1956.

GGA Göttingische gelehrte Anzeigen.

GM Gentleman's Magazine.

$H A S$

Académie des Sciences, Paris. Histoire.

$H A S / \mathrm{Ber}$

Akademie der Wissenschaften, Berlin. Histoire.

JB

$J H I$

Royal Society of London. Journal Book.

$J P$

Journal of the History of Ideas.

Journal de physique.

$M A S$

Académie des Sciences, Paris. Mémoires.

$M A S / \mathrm{Ber}$

Akademie der Wissenschaften, Berlin. Mémoires.

Mss. Gal.

Manoscritti Galileiani. Biblioteca Nazionale-Centrale, Florence.

NCAS

Akademiia nauk S.S.S.R., Leningrad. Novi commentarii academiae scientiarum imperialis petropolitanae.

$P T$

Royal Society of London. Philosophical Transactions.

RHS

RS

Revue d'histoire des sciences et de leurs applications.

RS Edin.

Royal Society of London.

Sloane Mss.

Royal Society of Edinburgh.

$V E$

Sloane Manuscripts. British Library, London.

VO

Alessandro Volta. Epistolario. 5 vols. Bologna, 1949-55.

Alessandro Volta. Le Opere. 7 vols. Milan, 1918-29.

\title{
NOTE ON CONVERSIONS
}

The basic units of reference are the Paris livre of 1726 (silver) and the louis of 24 livres (gold). The value of any other currency is taken as the ratio of its precious metal content, as given by Martini, Metrologia (1883), to that of the livre or the louis. Some frequently used conversions:

Currency

Livre

British pound/guinea

Dutch florin

Reichsthaler

Swedish daler (copper)

$\begin{array}{cc}\begin{array}{c}\text { Symbol } \\ \#\end{array} & \text { Equivalent } \\ \text { f/gn. } & 25 \# \\ \text { f. } & 2 \# \\ \text { RT } & 4 \# \\ \text { Dkmt } & 1 / 3 \#\end{array}$

